\title{
XI. Pollentia-Urbs Salvia during the Republican period
}

\author{
Roberto Perna, University of Macerata
}

\section{Introduction}

The numerous archaeological discoveries of the last twenty years have clarified many issues related to the genesis of the first settlement nucleus and colonial establishment in the town of Pollentia-Urbs Salvia during the Gracchan period. ${ }^{1}$ This is a time range of great interest, during which, in particular since the Hannibalic war, Rome was accelerating, and directly and systematically focusing on the cultural transformation processes of the territory conquered in the Italic area. ${ }^{2}$ Within this phase, the case study of Pollentia-Urbs Salvia (Fig. 1) is surely remarkable, because in the area which would become part of the Regio $V$, the strategy implemented by Rome during the second century $\mathrm{BC}$ was different from that of the previous century. This is because in areas already significantly integrated from a political and cultural point of view, the objective was to reorganise the methods used for management through a more systematic occupation and integration of the region. ${ }^{3}$

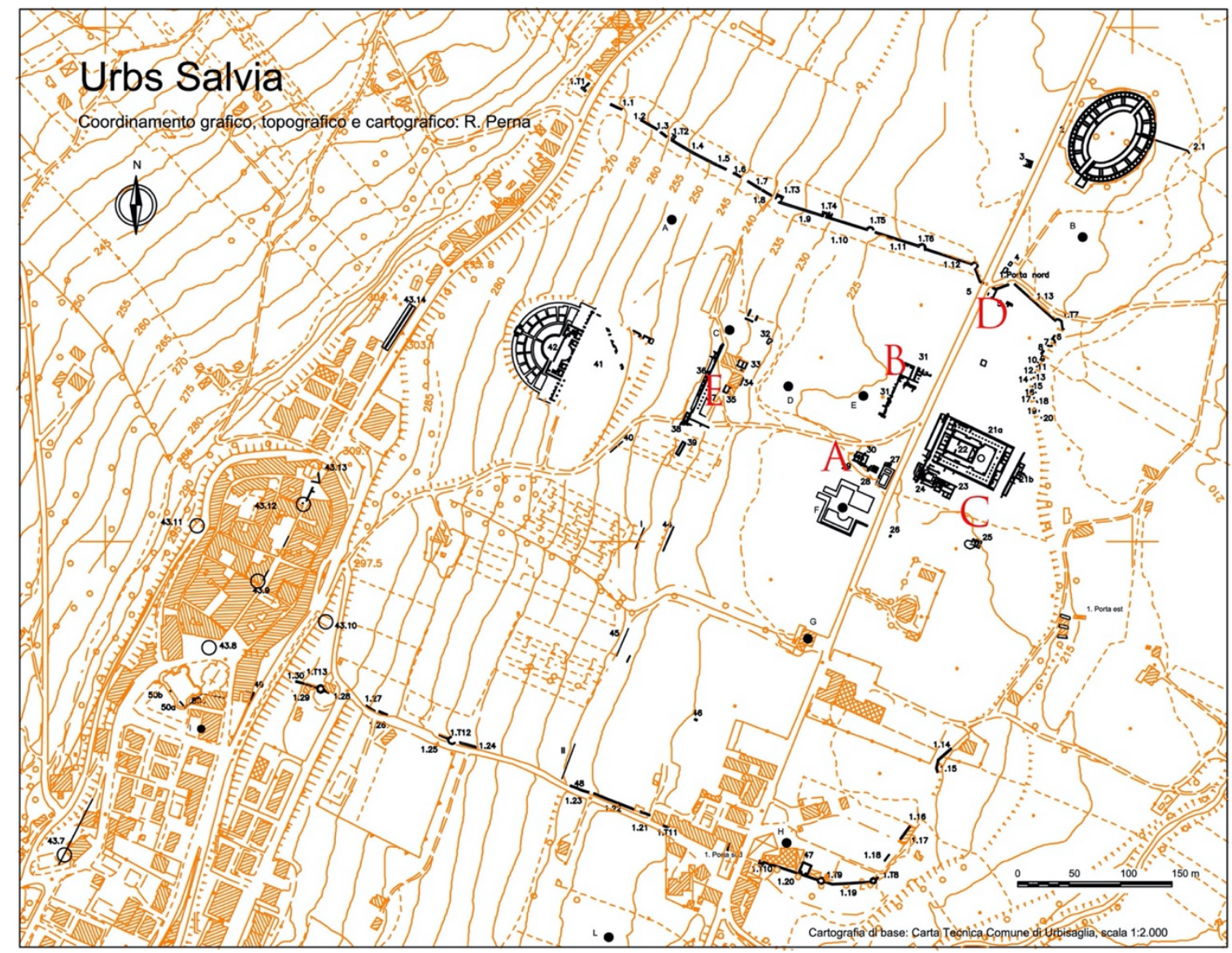

Fig. 1 Archaeological map of the city of Pollentia.

\footnotetext{
${ }^{1}$ Perna 2006; Fabrini 2013; Paci 2016; Perna 2018.

${ }^{2}$ Lippolis 2018.

${ }^{3}$ Fabrini 2013, with bibliography.
} 


\section{The phase of the conciliabulum}

\section{The settlement}

The first traces of occupation in the area have been identified at the southwestern limits of the colonial forum ${ }^{4}$ ( $A$ in Fig. 1) and are related to a craft complex from which some furnaces were found, three of which were well preserved (Fig. 3). ${ }^{5}$ Two (A and B; Fig. 2) were placed side by side with a north-south orientation and a third (C) with an east-west orientation, belonging to a first phase of the complex. ${ }^{6}$ These are very simple structures, based on the Type la open oven system designed by Cuomo di Caprio. 7

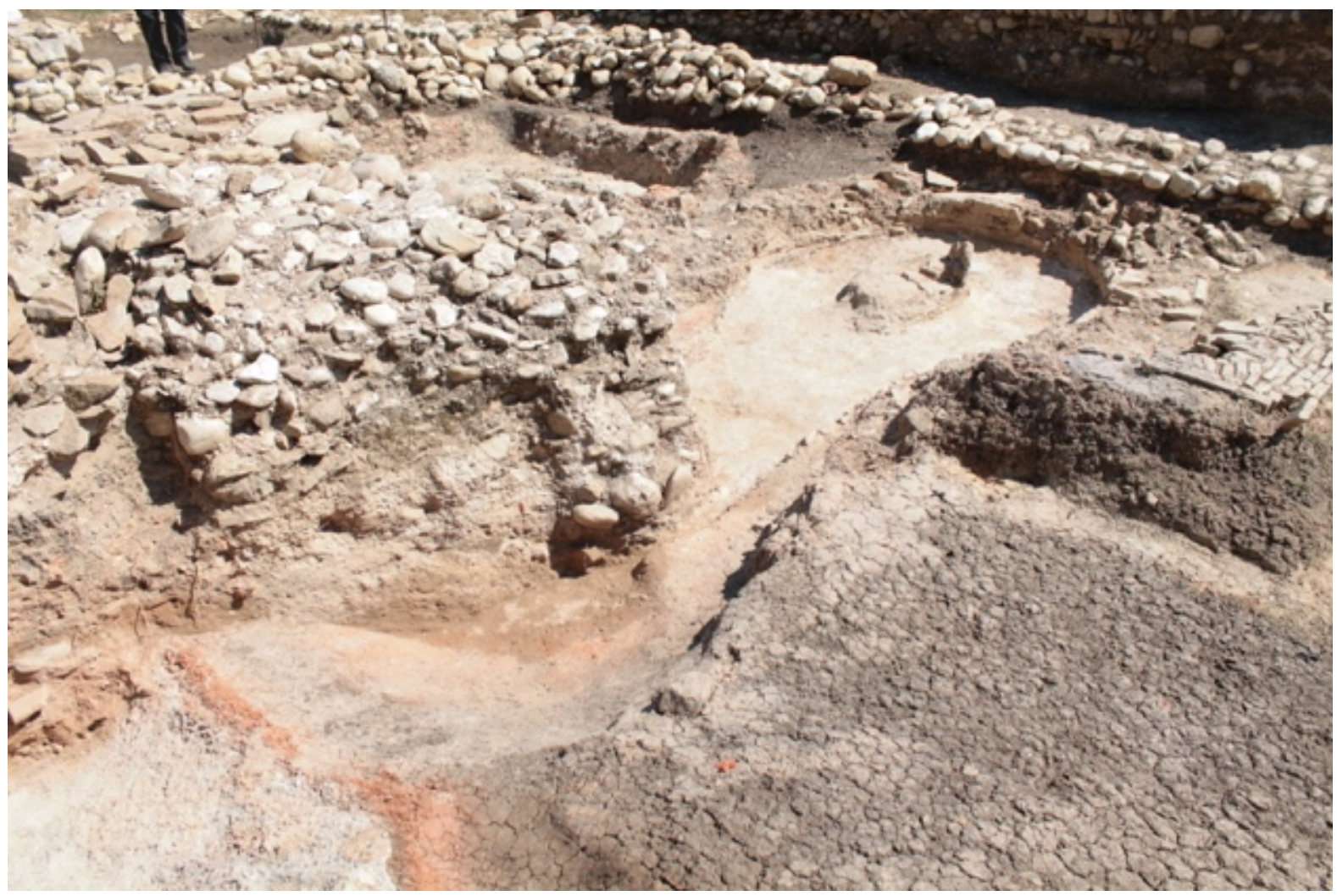

Fig. 2. Urbisaglia: Furnace B from North-West and the emblema in the southern room.

The complex, which was in use during the first half of the second century $\mathrm{BC}$, was used for the production of ceramics for domestic use, with morphological traits similar to those found in the Tyrrhenian area and, perhaps, of small amphorae. ${ }^{8}$

These are the remains of a settlement that in this phase had to extend at least to the northern limits of the area then occupied by the forum (B in Fig. 1), where the existence of some levels of contemporary

\footnotetext{
${ }^{4}$ The area was investigated through 4 trenches (Fig. 3): Trenches 1-3 covered the short south side, Trench 4 the north side (Sectors 1, 2 and 3) and part of the long west side (Sector 4).

${ }^{5}$ Perna 2014, 703-719; Perna 2018, 407-409.

${ }^{6}$ Traces of at least one other small kiln were found in the area immediately further east: Perna 2006, 71, nr. 30. A forge was later added to the craft area.

${ }^{7}$ Cuomo di Caprio 2007, 504.

${ }^{8}$ Perna et al. 2016, 267-280.
} 
frequentation has been highlighted. ${ }^{9}$ These levels are characterized by reduced structural remains (Fig. 4), which do not allow a planimetric reconstruction of the buildings to which they belonged. They were built with river rounded pebbles of small and medium size, held together with earth and can be attributed to the remains of foundations. These structures are placed on levels of clay soil, containing, among other remains, black gloss pottery, as well as a few thin-walled ceramics and internal red slip ware that allows these structures to be placed as still in the first half of the second century BC.

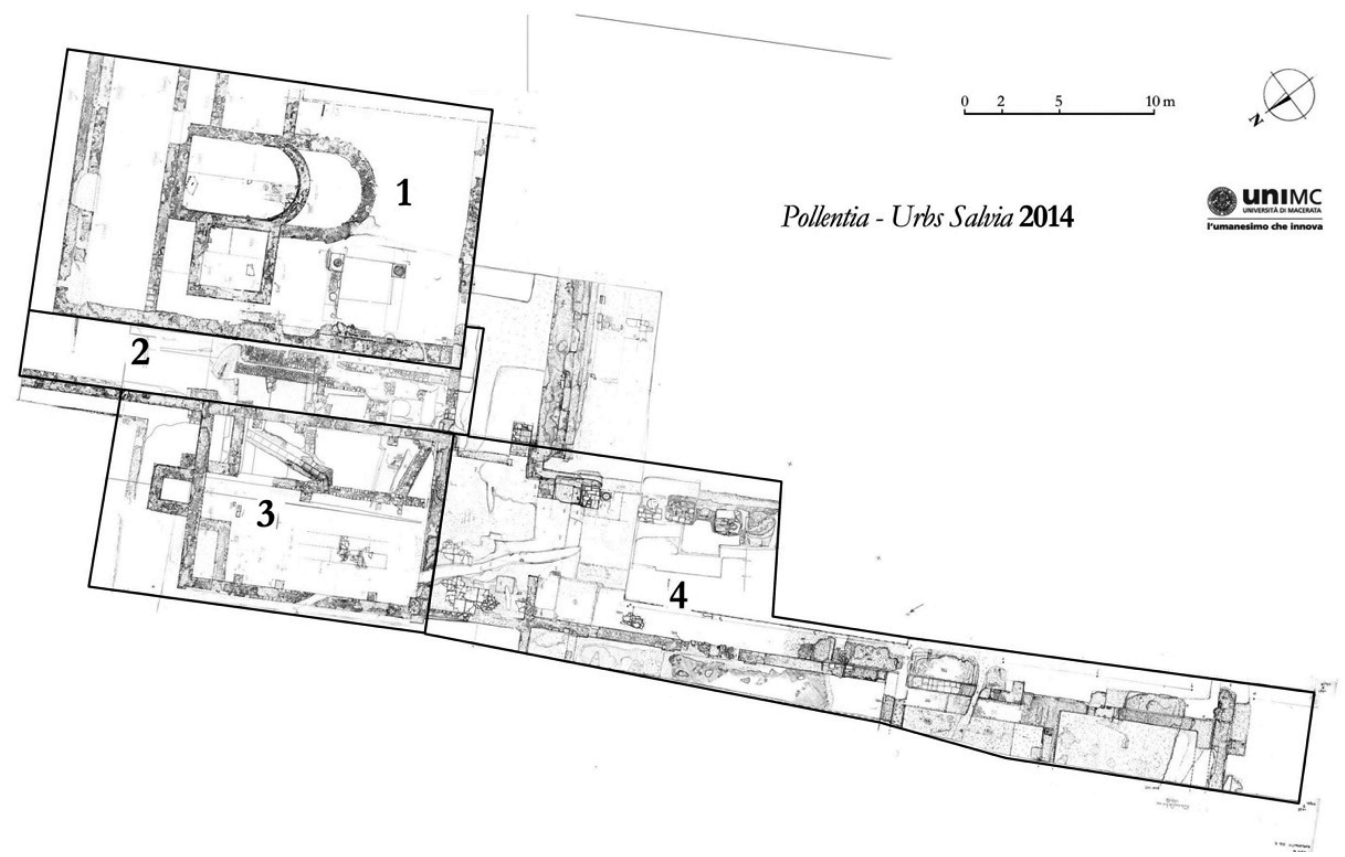

Fig. 3. Urbisaglia: Excavation Area 4.

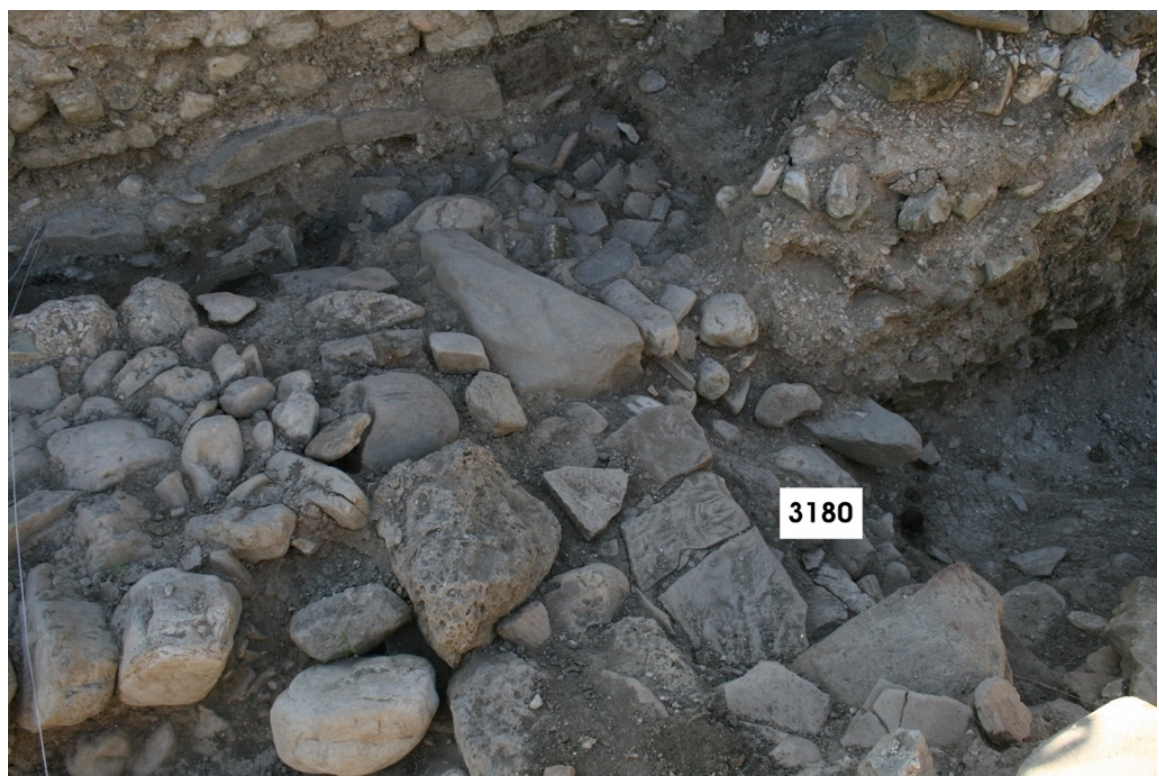

Fig. 4. Pollentia: foundations of the Republican age in Sector 2 of Excavation Area 4, from the south-east.

\footnotetext{
${ }^{9}$ In Sector 2 of Trench 4: Fabrini and Perna 2015, 4.
} 
Traces of this first phase of occupation in the area, datable from the middle of the third century $\mathrm{BC}$, also come from the area east of the forum, divided by the passage of the via Salaria Gallica (C in Fig. 1). ${ }^{10}$ These are materials found in late Republican layers: in particular black gloss ceramics produced both locally and regionally in the formal repertoire of Etruscan-Latin, Etruscan and Campana A, but also imported from the same areas.

Elements such as the black gloss ceramics seem to be a significant indicator of Romanization. ${ }^{11}$ These remains indicate the birth of a settlement linked to the probably spontaneous presence, in part of the ager publicus not affected by the lex Flaminia (232 BC), of settlers from the Etruscan-Latin area. The settlement could, therefore, be characterized as a conciliabulum. ${ }^{12}$ Perhaps it was one of those vici in the main Roman settlement structure in Italy organized with vici and pagi for which the via Salaria Gallica certainly played an organising role. ${ }^{13}$ Organizationally, the settlement would seem to be characterized by empty spaces and occupy a large area, over a length in the north-south direction of at least $200 \mathrm{~m}$, which stretches from the Republican forum to the area of the Augustan walls in the north.

\section{A worship area?}

The most recent research has made it possible to hypothesise the presence of a sacred place in the area then occupied by the theatre, near spring waters and perhaps in the open air. This sacred place must have been linked to the first community, and is suggested by a structure of Imperial age incorporated within the upper part of the south-west sector of the ima cavea. ${ }^{14}$ The non-central location with respect to the cavea, the north-eastern orientation and the fact that it compromises the path, limiting the functionality of the building, are elements which have aided its preservation. This interest in preservation was still active in the Tiberian period and can be explained by the will to respect a sacred place.

Assuming that the cult was not linked to local communities before the third century BC, it is possible that the traces of an ancient cult, connected to the concilabulum and located in a peripheral area rich in spring water, could be identified in these remains. ${ }^{15}$ The cult has been assigned to the Bona Dea, whose healing and health-related attributes probably derive directly from the Agathé Théos and therefore from the Greek Igea, evidently related to springs and areas rich in water. The identification of a sacred place before the colonial foundation would shed new light on how the first group of settlers organized themselves, confirming the Roman intention in the area to use the institution of new cults as a tool for the processes of territorial appropriation. ${ }^{16}$

\footnotetext{
${ }^{10}$ Fabrini 2003; Perna 2014, 703-719 and Perna 2018, 408-410.

${ }^{11}$ Stek 2009, 23; more specifically with regard to the regional context see Mazzeo Saracino 2014, 357-390.

12 Perna 2014, 702-706; Perna 2018, 408-410; Perna in press (b).

${ }^{13}$ Tarpin 2002; Todisco 2011; Stek 2009; Perna 2019.

${ }^{14}$ Cingolani in press; Cingolani and Perna in press (a); Coarelli 1993; ThesCRA IV, see: fanum (Torelli) and lucus (Comella).

${ }^{15}$ On the cult as an identifying element of a community from its earliest stages of life see Lippolis 2017, 398-400; 405-406 and Orlin 2003.

${ }^{16}$ In the territory of regio $V$ and in the ager Gallicus there is a significant caesura in the life of places of worship between the third and second centuries BC: Perna et al. 2013; Perna 2018, 425. There are in fact very few (11 out of 263) testimonies related to the cult that can be dated between the two periods, less than 35 of those belong to the Iron Age and 124 exclusively to the Roman period. In general, see in this regard Stek 2009, 18.
} 
This is a process already known in relation to the Lucus Pisaurensis ${ }^{17}$, occupied at least a century before the colony of Pisaurum, or that of Sena Gallica, where the urban structure of the colony seems to have been preceded by that of a cult shared by the members of the new community. ${ }^{18}$

The presence of a craft area and a sector for worship is therefore fundamental to understanding the functions of the settlement, whose name must therefore be associated with the later polyonym Urbs Salvia ${ }^{19}$ confirming a direct link between Salvia and Salus, which was to function as a service centre for the territory characterized by an early Romanization, but which only seems to be affected by intermittent presences until the end of the second century $\mathrm{BC} .{ }^{20}$

\section{The colonial foundation in the Gracchan era}

At the end of the second century $\mathrm{BC}$ the area of the oldest conciliabulum was involved in processes of substantial reorganization, documented in particular by the excavations conducted in the area of the forum ${ }^{21}$.

\section{South side of the forum area}

The craft complex was in fact destroyed for the construction of a building (A in Fig. 1; Fig. 5) made up of two equally-sized rectangular rooms preceded by a portico delimited on the outside simply by a low wall. ${ }^{22}$ Considering the dimensions, the plan, the topographic location delimiting the south-west corner of the Republican and Imperial forum, the presence of a foundation sacrifice and the presence, in the two rooms, of emblemata in opus spicatum to support and highlight elements placed in a prominent position (two altars?), it is possible to hypothesise a cultic function (Fig. 6). ${ }^{23}$

It must be remembered that, in terms of the plan and building techniques, these chronological phases are still characterized by the construction of very simple structures, with plans linked to individual and specific divinities and cultural needs (Vitruv. IV, 8,6$){ }^{24}$

The destruction levels of the kiln were covered by earthy matrix layers characterized by the presence of black gloss ceramics and amphorae, which places the destruction of the kiln at least at the end of the second century BC, in line with the stratigraphic contexts related to the construction of the building.

Two circular pits (about $40 \mathrm{~cm}$. in diameter), identified to the east of the Republican Building and used for fixing poles belong to the same construction phase. ${ }^{25}$ These remains testify to the period before the

\footnotetext{
17 Di Luca 2004; Coarelli 2000, 195-205; Bandelli 2008, 336-351; Belfiori 2017.

18 Lepore et al. 2012b, 1-30. In this case, however, the connection between the first demic centre and the urban organization of the colony is considered very close, as two phases of the same founding moment.

${ }^{19}$ It would therefore explain the origin of the poleonym Urbs Salvia until now unknown: Paci 2016: 41; Perna in press (b).

${ }^{20}$ Perna and Capponi 2012, 149-164; Perna 2009, 95-101; Perna 2014, 710-719; Paci 1995, 30-34; Bandelli 2007, 16; de Marinis and Paci 2012, 93-104; Perna 2018.

${ }^{21}$ R. Perna in Fabrini and Perna 2010; Fabrini and Perna 2013; Fabrini and Perna 2015.

22 Perna 2014, 707-708; Fabrini 2003, 132-135; Perna 2018, 410-413;

${ }^{23}$ The foundation sacrifice in cult buildings - and others - was a widespread practice that reinforced the sacredness of the place. Also noteworthy are fragments of black painted ceramics placed at the corner between two walls of the building (US 799).

${ }^{24}$ Bertrand 2017, 44-45; Lippolis 2018, 36-37.

${ }^{25}$ Perna 2006, 70, nr. 27.
} 
first Augustan age and can be compared with the fences of the Concordia forum, made around a tree, and later replaced by poles or pilasters. ${ }^{26}$

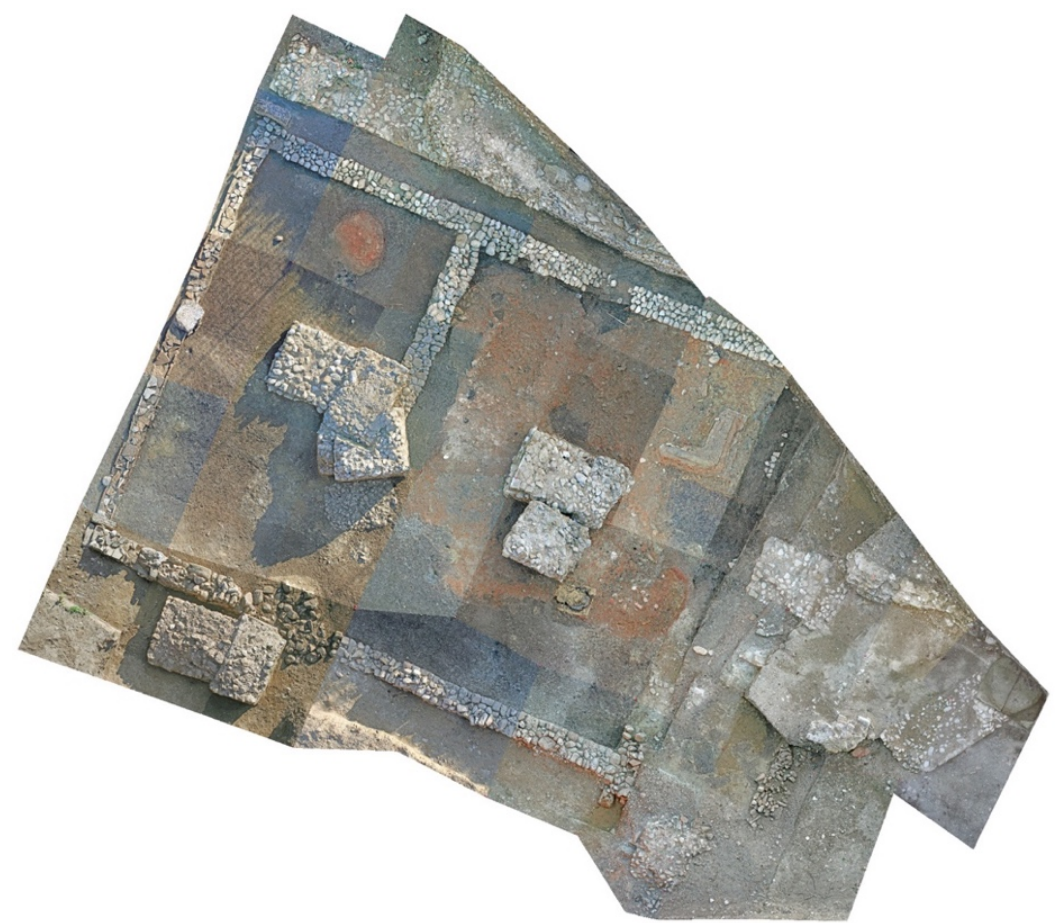

Fig. 5. Pollentia: plan of the Republican building.

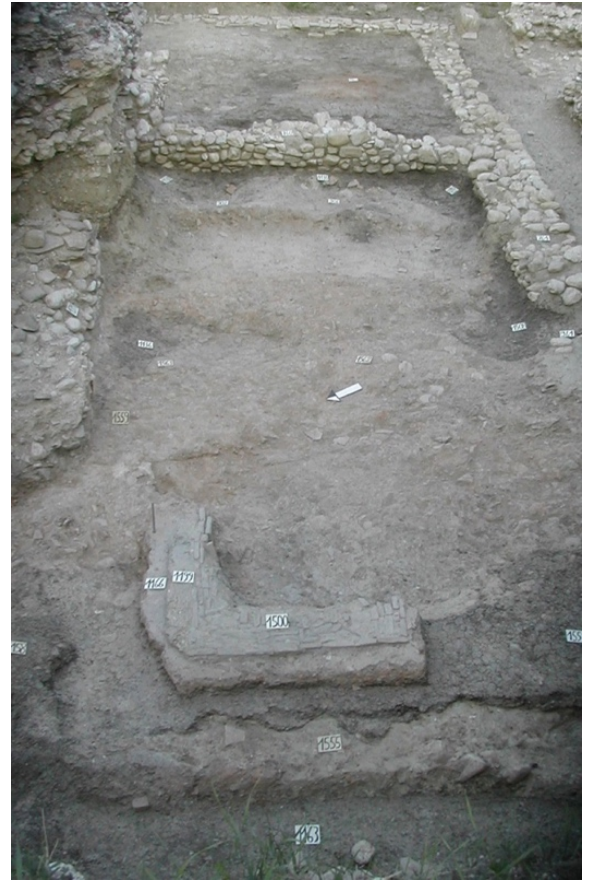

Fig. 6. Pollentia: Republican building, the emblema in the southern room from the south-west.

${ }^{26}$ Croce da Villa 1995, 205-7. 


\section{North side of the forum area}

Excavations carried out on the northern side of the forum square have brought to light a series of rooms with preserved foundations made with river pebbles and bound by mortar (Figs. 3, 7), and which were probably linked to structures built with perishable materials, represented by traces of post-holes indicating the presence of a pitched roof. ${ }^{27}$ This phase seems to end following a fire, which might have been caused by humans. ${ }^{28}$

In the same area, under the later porticus duplex dating back to the proto-Augustan age, levels of collapsed structures, perhaps made of raw bricks and wooden beams, have been identified. ${ }^{29}$

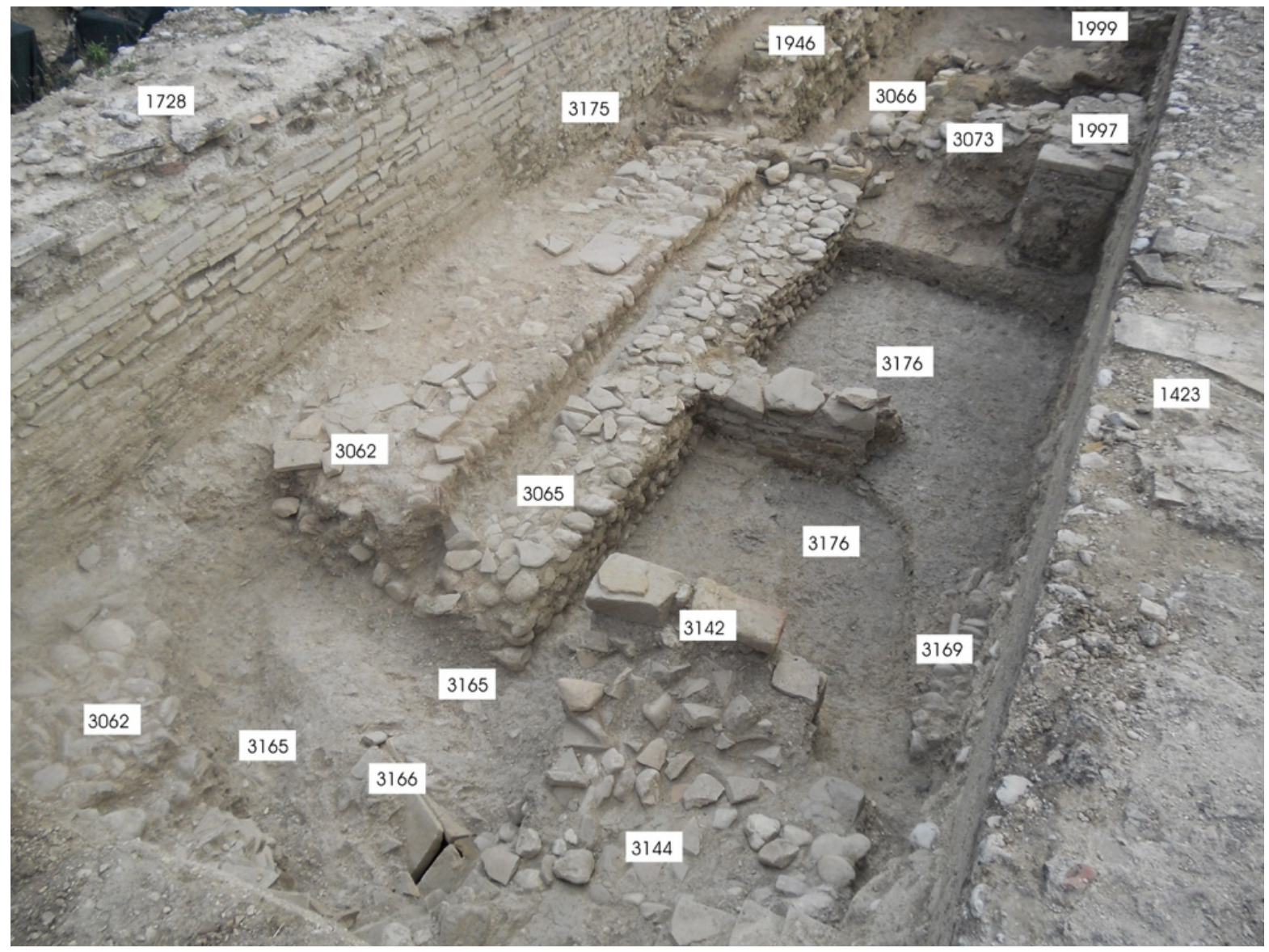

Fig. 7. Pollentia: walls of Republican age in Sector 2 of Excavation 4, from the south-east.

Along the west side of the forum is a building with an earthen floor and raw brick walls, covered with thick levels of collapse, rich in coal and fragments of burnt beams. These remains allow us to place this destruction in the Republican age, and in relation to what was identified in Sectors 1, 2 and 3 of the same Trench $4 .{ }^{30}$

\footnotetext{
${ }^{27}$ Fabrini and Perna 2015.

${ }^{28}$ Perna 2014, 708. The levels on which these structures are implanted are made up of clay matrix earth, which has returned, in addition to amphorae and ceramics of common use, black gloss ceramics and internal red slip ware still framed at the end of the second century BC.

${ }^{29}$ Fabrini 2009a, 206-212.

${ }^{30}$ R. Perna in Fabrini and Perna 2010, 10; Perna 2014, 708.
} 
Excavations carried out in the area below the temple-cryptoporticus complex, separated from the forum by the via Salaria Gallica, have brought to light structures chronologically located at the end of the second century BC (Fig. 1.C). ${ }^{31}$ Notably, there is a floor plan, covered by levels of abandonment, that may date to the middle of the first century $B C$, obliterated by cobblestone walls dating back to the late Republican period. We would also mention, immediately south-east of the so-called small temple, levels of occupation dating back to the end of the second century BC. Later the area was occupied by four stretches of walls, made of pebbles bound by mortar that seem to form a complex made up of various rooms. It therefore seems possible to hypothesise that a residential area with domus had been established along the east side of the forum at two different times: one at the end of the second century $\mathrm{BC}$ and the other in the late Republican age.

\section{The productive area}

The most ancient phases are documented at the North Gate of the Imperial era town by a cobblestone wall flanked by a small channel which, along with many manufacturing scraps and levels of baked clay, seems to testify to the organization of an industrial area that can be placed chronologically between the end of the second century BC and the Augustan age, when the area was abandoned and used for the expansion of the new town walls (Fig. 1.D). ${ }^{32}$

\section{The town}

A cult building and numerous other remains found in this area can be dated from the beginning of the second century BC and can be associated with the foundation of a Roman colony promoted by Gaius Gracchus (probably around $123 \mathrm{BC}$ ). ${ }^{33}$ It was probably called Pollentia, considering the passage of Plinius' Urbe Salvia Pollentini, which combines the oldest ethnic name with the following poleonym Urbs Salvia (Plin., Nat. Hist. III,13, 111) ${ }^{34}$.

The Capitolium of the colony was not placed in the forum, although the investigations conducted in the four corners did not allow the characteristic buildings of the square to be identified. It has therefore been hypothesized that its remains can be associated with a concrete base, $11.00 \times 1.8 \mathrm{~m}$ in size and $1.30 \mathrm{~m}$ in height, which can be identified as part of the podium of a monumental building (E in Fig. 1). ${ }^{35}$ In the phases of Tiberian-Claudian expansion, this would have been highlighted in the centre of the

\footnotetext{
${ }^{31}$ Fabrini 2000, 122-126, Fabrini 2001, 10; Fabrini 2003, 116-131; Fabrini 2005, 23; Fabrini 2007, 309-347; Fabrini 2009a, 193-242; Fabrini 2009b, 1-10; Fabrini 2012, 281-308 Perna 2006, 58-62; Fabrini in Fabrini 2013, 89-97; Montali 2013, 119-142.

32 Perna 2006, 53-56; Perna 2014, 709-710.

${ }^{33}$ Already hypothesized on a historical basis taking into account the fact that the praetura represents the highest administrative charge in Urbs Salvia, as in the cases of the colonies of Potentia, Pisaurum and Auximum: Paci 1990, 71-97; Paci 1999, 227; Perna 2014, 703-719, Perna in Fabrini and Perna 2015, 1-7 and Perna 2018, 407-420 (for archaeology); Paci 2013, Paci 2015 and Paci 2016 (for epigraphy).

${ }^{34}$ C.I.L. IX, 526; Humbert 1978, 244, note 158; Delplace 1993, 89; Paci 1999, 227.

35 Perna 2006, 76-77; Perna 2007, 349-387, Perna 2014, 703-719.
} 
square by the so-called 'Edificio a Nicchioni', overlooking the forum and the flatter part of the urban area $^{36}$.

The building would have respected the east-facing orientation, traditional for Roman architecture, placing it in a predominant position with respect to the forum itself and the town. ${ }^{37}$ As in Rome, therefore, the building stood in excelsissimo loco, on the edge of the second order terrace, in compliance with Vitruvian prescriptions. This position would have allowed the polyadic deity to overlook a large part of the urban extension. The characteristics of the emplekton lead back to a phase certainly subsequent to that of the buildings chronologically situated at the end of the second century BC, but earlier than that of the structures built in the post-Augustan age.

As far as the urban definition of the town is concerned, it can be assumed that it occupied only the area on the plain, on the third order terrace and straddling the main roadway at the bottom of the valley defined by the via Salaria Gallica. The northern limit of the town was the area of the kilns identified near the North Gate, located in a zone immediately out of town, but nothing can be said with certainty about the south side (Fig. 8). ${ }^{38}$ To the east the terrace on the river Fiastra acts as a boundary, while to the west the town reaches the edge of the second order terrace, with the Capitolium in a peripheral but dominant position. The programmatic plan is based on wheelbases of $2 \times 3$ actus, $^{39}$ a module widespread in the Republican age, ${ }^{40}$ into which is inserted the forum square, whose space seems to be limited to the south by the Republican building of worship. To the north, mirrored with respect to the axis of the Augustan age square, are the late Republican buildings on which the porticus duplex of the early Augustan age is aligned, while to the west the boundary reached at least as far as the line still marked by the Augustan age arcades, of which three column bases are preserved.

The forum would have occupied the central area of the space delimited by two blocks, perhaps with the entrance from the west placed in a central position with respect to the long side, longitudinally with respect to the main roadway defined by the via Salaria Gallica and tangential to it, therefore oriented according to extremely widespread models found just after the third century BC ${ }^{41}$. Taking into account the continuity of its limits, only later monumentalized until the Augustan age, the occupied area would have correspond to $1.5 \%$ of the area of the city, very close to the average size of the contemporary fora ${ }^{42}$. A comparison with the neighbouring colonies of Potentia and Pisaurum (second century BC), which from the orographic point of view allowed a similar planning freedom, seems to confirm the trend of organising fora with the same close relationship to the road network. ${ }^{43}$

\footnotetext{
${ }^{36}$ The structures must have been more visible at the end of the nineteenth century, when Pallotta in his general plan of the city, precisely in this point, places the "Vestigia di un tempio": Pallotta 1881, tav. 1.

${ }^{37}$ Vitruv. IV, 5, 2: "Sin autem loci natura interpellaverit, tunc convertendae sunt earum regionum constitutiones, uti quam plurima pars moenium e templis eorum consipiciatur"; Gros 1997, 484, nrs. 188, 189.

${ }^{38}$ Perna 2006, 113-124; Perna 2007, 349-387.

${ }^{39}$ While in the area on a greater slope to the west, occupied by the post-Augustan expansion they are larger $(2 \times 2$ actus).

40 Perna 2006, 113-124; Sommella 1988, 120-121; Gros and Torelli 1988, 147-150; Conventi 2004, 229-234. The walls remain a partly open problem, an element which, even in compliance with Vitruvian canons, identified a complex as being urban (Vitruv. I, III, 1; I, V 1-8); hypothetically the possible extension of the Republican city would go from 152,000 to $193,000 \mathrm{~m}^{2}$ (Perna 2006, 113-124).

${ }^{41}$ See for example, with particular reference to the cities of Emilia Romagna, Lippolis 2000, 107.

${ }^{42}$ Conventi 2004: 159-165.

${ }^{43}$ As far as Potentia is concerned, the city's layout seems to be organized on the basis of regular blocks in relation to which the sacred area of the Forum (occupied by the temple and portico complex) is arranged longitudinally with respect to the main roadway marked by the via Salaria Picena: Vermeulen and Verhoeven 2004, 61-9; Vermeulen et al. 2017. As far as the Pisaurum is concerned, although it is difficult to identify the exact location of
} 


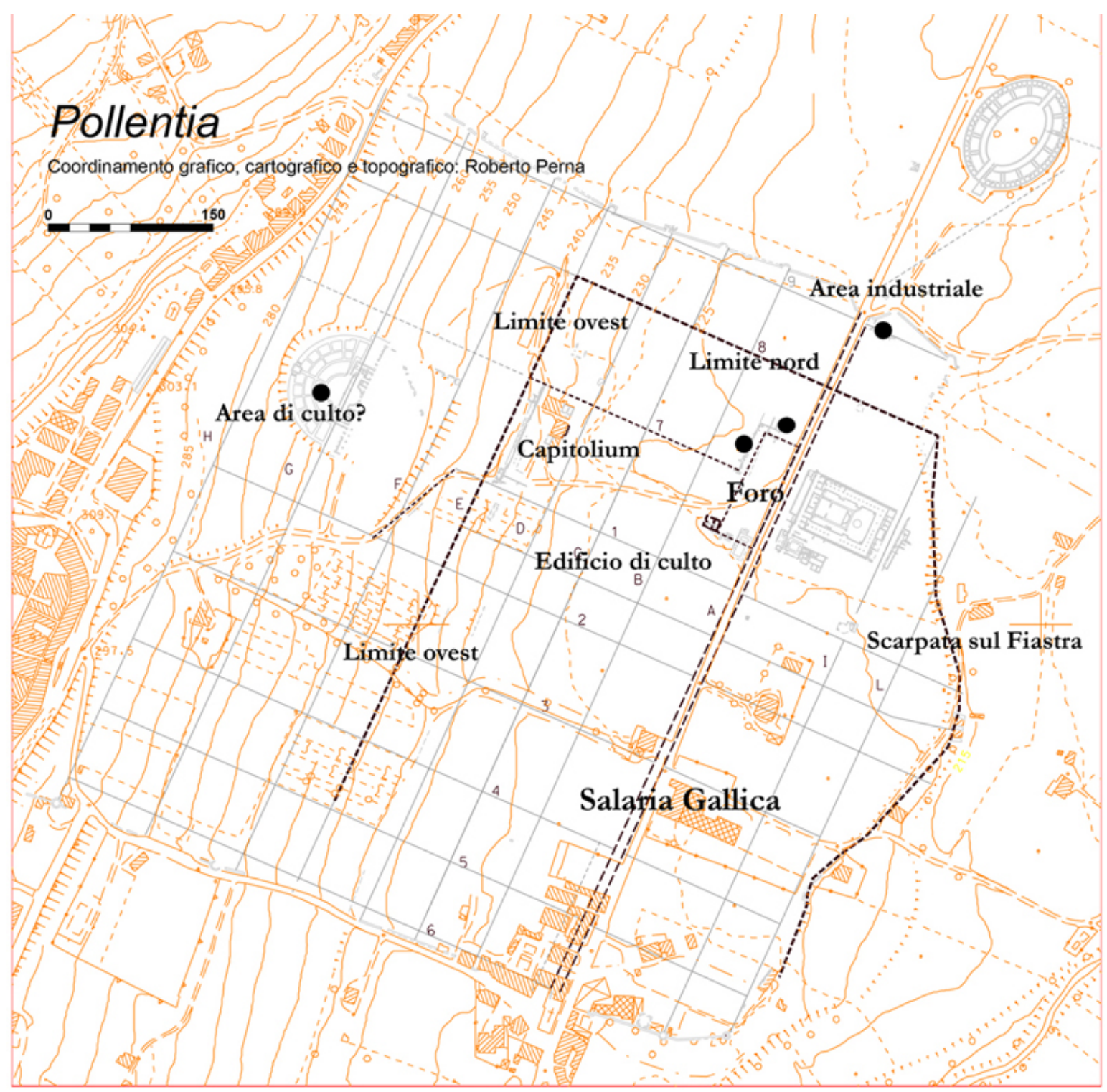

Fig. 8. Pollentia: the city of Republican age (the later structures in grey)

Finally, several items show that urban spaces and their functions were soon defined when the colony was first founded. This urban planning was then progressively developed and maintained until the Augustan age. They are the following items: the location of the sacred building at the south-east corner of the forum, which would remain the same and with the same orientation even after the urban reorganization of the Imperial age; the displacement of the craft quarters to a peripheral area, probably extra moenia, which would be abandoned only at the time of the construction of the Augustan walls; the construction of important buildings east of the via Salaria Gallica; and the building of the Capitolium. The intense development of the city since the end of the second century BC seems to be confirmed by

the forum, it seems plausible that it extended under the current Piazza del Popolo, parallel to the main road network and not crossed by it: Di Cocco 2004, 54-55. 
data from the study of materials coming from urban excavations. ${ }^{44}$ They testify that the centre began to integrate itself into the context of important trade routes which had both a central-Italic and Mediterranean character. ${ }^{45}$

The oldest conciliabulum was therefore reorganized as a Gracchan colony for the arrival of new settlers. This is attested by at least three series of centurial delimitations of 15 actus and by a series of farms that in this phase mainly occupy the hilly areas overlooking the valley. ${ }^{46}$

The Republican town seems coherently inserted within the centuriation, of which it occupies half a centuria arranged in an east-west direction. The city lies at the boundary between the second and third order terraces and its west side corresponds with an internal limit (intercisivus), while the remaining space in the north-south direction, still corresponds to half a centuria (Fig. 9). In the first case it should also be noted that the urban limit corresponds to the point where the east-west axis of the Imperial town bends diagonally towards the south, perhaps following the access route to the town in Republican times (1 in Fig. 8). ${ }^{47}$ The presence of social groups linked to the exploitation of the countryside that would have characterized this phase of reorganization of the territory would also be reflected in the materials identified in the foundation sacrifice of the cult building at the southwest corner of the forum, among which the presence of sickles is noted ${ }^{48}$.

\section{The territory}

Centuriation, systematic occupation of the territory and urban foundation seem to be part of a more articulated and complex organizational system, in which the individual components are integrated in a coherent way (Fig. 9). After the end of the second century BC, the formation of two centres began. The first was located at Colli Vasari and the second at Casa Mori and both lie at the limits of the centuriated areas. ${ }^{49}$ Similarly, the rustic villas of greater dimensions are organized on the margins of the centuriated areas in this phase. These are: the site of Villamagna located on the limit of the second centuriation; ${ }^{50}$ the site near 'il Vallato' at the end of the third centuriation; the site located at Casa Bandini on the northern border of the second centuriation; the sites located at Casa Giustozzi and Case Cicconi in the liminal areas (subseciva) between two different blocks of the second centuriation (Fig. 9. C, D); and

\footnotetext{
${ }^{44}$ Giuliodori et al. 2007, 389-449.

${ }^{45}$ Attested in particular by the production of thin walls, Italian Megarian bowls, wine amphorae and black gloss pottery: M. Giuliodori in Giuliodori et al. 2007, 391; Giuliodori and Tubaldi 2014; Forti 2006, 357-366; S. Forti in Giuliodori et al. 2007, 413-420.

46 Perna 2014, 710-714.

47 Perna 2006, 115-118, fig. 113.

${ }^{48}$ Fabrini 2003: 135, nota 63; Perna in press (a); Scheid 2017, 240-242. On the presence of iron materials in votive offerings related to foundations of places of worship see Lippolis 2017, 408. Also worth mentioning is a black gloss pyxis, of the Morel 7500 type, which can be dated between the second half of the second and the first half of the first century $\mathrm{BC}$ with a graffito inscription $T(i t-) \mathrm{Ve}(---)$, which finds comparison with a fragment of a cup of the same class, sporadic from the area of the temple-cryptoporticus complex, framed in the third-second century BC and also with graffiti inscribed $M$ (arc-) Ve(---): Antolini 2018. The objects, perhaps referring to members of the gens Vettia, seem to document the presence of individuals with a fully Roman onomastic, who use typical categories of worship to assert their identity in the context of urban structuring processes.

49 Perna 2014, 713-714; Perna 2005, 18, Necropoli I (Fig. on page 11) where an outcrop area with an extension of about $1500 \mathrm{~m}^{2}$ characterized by a large concentration of ceramics, especially fire, bricks and stones, has also returned fragments of a polychrome mosaic with black bands and rectangular emblem in sandstone and marble, with a central drain hole. An analysis of the black gloss coming from it makes it possible to place it chronologically at least in the second century BC.

${ }^{50}$ Paci and Perna 2015; Perna 2005, 19, Fig. page 11 (A, B, C, D); Perna 2014, 713-714.
} 
finally the site identified at Case Caraceni in the middle of the residual space between the three centuriations and along the via Salaria Gallica, in a favourable position near the Fiastra river (Fig. 9.E). It seems that the collocation of the necropolis in areas outside the centuriations, active also in the Imperial age, is also defined in this phase ( $\mathrm{N}$ in Fig. 9). ${ }^{51}$

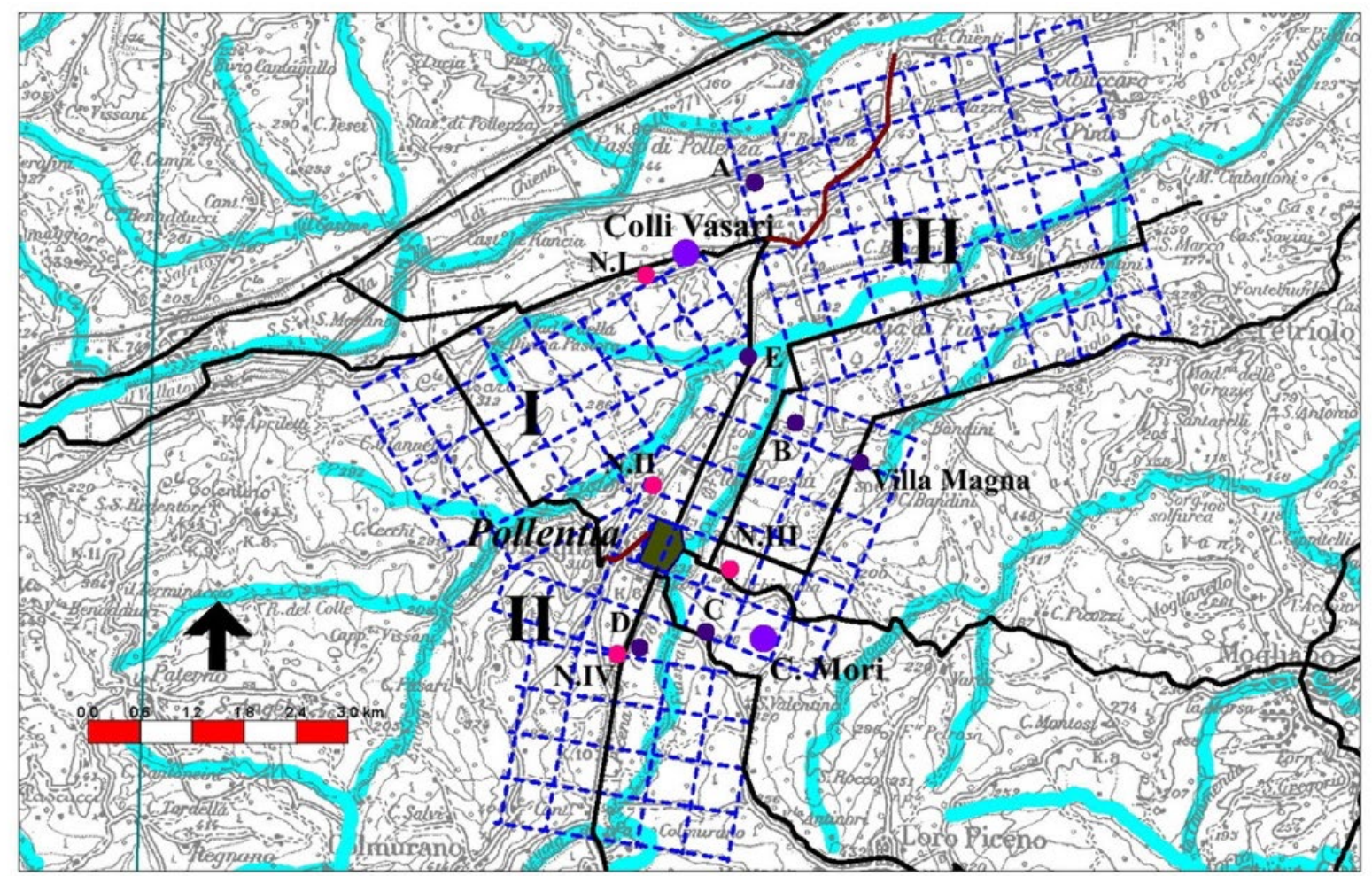

Fig. 9. Pollentia: archaeological map of the territory

The fundamental role of the territorial organization cannot be separated from the passage of the via Salaria Gallica, an axis of penetration to the north from the third century BC, and an element of functional infrastructure for economic and social development during the second century BC. This road in fact directly connected the territories of the Chienti and Fiastra valleys to the areas of Ancona (Lib. Col. I, 227, 1-3) and Auximum (Lib. Col. II, 253, 1-2), affected by the Lex Sempronia..$^{52}$ This is therefore a territorial context of particular interest during the second century $\mathrm{BC}$, particularly in relation to the use of the port of Ancona. This port, also thanks to the establishment of the duumiviri navales, is entirely included in the Roman defensive system. ${ }^{53}$ These trends, together with the economic reorganization, within the increased interest for the trade linked to the eastern Mediterranean sector, contributed to make the Rome-Ancona road a powerful axis of economic development for the territory. ${ }^{54}$

\footnotetext{
${ }^{51}$ Perna 2014, 714.

52 Perna 2019, 94; Branchesi 2007, 192-193; Delplace 1993, 170-172; Destro 2003, 101-116.

53 Tit. Liv., XLI, 1, 2. This is an important role confirmed by the landing in $20 \mathrm{AD}$ of Gnaeus Calpurnio Piso returning from Syria (Tac., Ann, III, 9).

54 Paci 2001, 73-87; Marengo and Paci 2008, 313-328; Micheli and Santucci 2010, 26-38; Paci 2010, 1-12; Cingolani and Perna in press (b).
} 